\title{
Management of Water Usage in East Aegean and West Aegean River Basin Districts of Bulgaria
}

\author{
Bulgaristan'ın Doğu ve Batı Akdeniz Nehir Havzalarında Su Kullanımının \\ Yönetimi
}

\author{
Zoya MATEEVA \\ Department of Geography, National Institute of Geophysics, Geodesy and Geography, \\ Bulgarian Academy of Sciences, Sofia, Bulgaria
}

\begin{abstract}
The study is aimed to investigate the conditions and problems of water supply system and waste water discharge \& treatment in East Aegean and West Aegean river basins of Bulgaria which territory comprises the highest mountains of the country. The work is based on original data gathered through specialized questionnaires amongst all the municipalities of these river basin areas. The demographic and the social-economic situation of the municipalities is also been explained for better analysis and understanding of the problems with waters, and their more successful solving and management. The work assists Ministry of Environment and Waters of Bulgaria in the implementation of the requirements of the EU Water Framework Directive (WFD) that includes preparation of the River Basin Management Plans for the East\&West Aegean River Basins as selected areas.

Keywords: Aegean river basins of Bulgaria; management of waters; water supply problems; water discharge problems; water pollution; floods; social-economic situation.

Özet: Bu çalışmanın amacl, Bulgaristan'da ülkenin en yüksek dağllk bölgelerini de kapsayan Doğu Akdeniz ve Batı Akdeniz nehir havzalarında su tedarik sistemindeki şart ve sorunların olduğu gibi bu bölgedeki atık suların boşaltılması \& işlenmesi ile ilgili şart ve sorunların da araştırılmasıldır. Araşstırma, anılan iki nehir havzalarındaki belediyelerde özel anketler düzenlenerek toplanan asıl bilgiler esas alınarak yapılmıştır. Su sorunlarının daha iyi bir şekilde analiz edilmesi ve anlaşılması ve daha iyi bir şekilde çözümlenmesi ve yönetilmesi için araştırılan belediyelerdeki demografik ve sosyal-ekonomik durum da incelenmiştir. Yapılan araștırma, Avrupa Birliği Su Çerçeve Direktifi'nin (Water Framework Directive, WFD) Doğu ve Batı Akdeniz Nehir Havzaları Yönetim Planı geliştirilmesini öngören hükümlerinin uygulanmasında Bulgar Çevre ve Su Bakanlığına yardımcı olmaktadır.

Anahtar kelimeler: Bulgaristan'da Doğu Akdeniz ve Batı Akdeniz nehir havzalarl; su temin sorunlarl; atık suları işleme sorunları; suların kirletilmesi; su baskını; Doğu Akdeniz ve Batı Akdeniz nehir havzalarında sosyal-ekonomik durum.
\end{abstract}

\section{Introduction}

This study is developed in the frame of the project "Integrated Water Management in the Republic of Bulgaria" that has been conducted by the Government of Japan, through the Japan International Cooperation Agency (JICA). The project realization is a response to the request of the Government of Bulgaria, according to the EU requirement that targets development of preferable status of all the water bodies in the area by the year 2015. The project has been carried out in accordance with the Scope of Work signed between the Ministry of Environment and Water (MoEW) of Republic of Bulgaria and JICA, Japan.

Based on the Water Act of 2000 the Government of Bulgaria has divided the whole country into four river basin management districts, and set up the following four river basin directorates (Fig.1):

- Danube River Basin Directorate (DRBD)

- Black Sea River Basin Directorate (BSRD) 
- East Aegean Sea River Basin Directorate (EABD)

- West Aegean Sea River Basin Directorate (WABD)

The study is aimed to investigate the conditions and problems of water supply system and waste water discharge and treatment in EABD and WABD areas. It is based on original data gathered through specialized questionnaires amongst all the municipalities of EABD and WABD. The demographic and the social-economic situation of these municipalities is also been explained for better analysis and understanding the problems with waters, and their more successful solving and management.

This way the work assists MoEW in the implementation of the requirements of the EU Water Framework Directive (WFD) which includes preparation of the River Basin Management Plans for the EABD and WABD as selected areas.

\section{General Information for the Municipalities}

\subsection{Demographic situation}

The scope of the survey includes 22 Bulgarian municipalities, fourteen of which are located in the East Aegean River Basin Region, and eight more in the West Aegean River Basin Region. The density of rural population in these municipalities varies between very low $(0-20$ persons $/ \mathrm{km} 2)$ to high (5-100 persons/km2) (Fig.2). The municipalities' centers are cities and towns of different categories with regard to population size - starting from "less than 5 thousand" and up to "between 300 and 500 thousand" (Fig.3), and the municipalities themselves have a population between approximately 10 thousand inhabitants (Municipality of Dospat) and 375 thousand inhabitants (Municipality of Plovdiv) (Fig.4). On average, the trends in population change show are towards decreasing number of inhabitants in these municipalities, but if we consider the two River Basin Regions separately we can find out that in the East Aegean River Basin Region the number of inhabitants of municipalities shows a strong trend towards decrease, while in the West Aegean River Basin Region shows a trend towards increase, though less expressed (Fig.5). With regard to age ratio, 'very aged population' type prevails in villages, and 'moderately aged' prevails in cities and towns. The municipalities of Velingrad, Gotse Delchev and Dospat are an exception with their predominantly 'young age' population (Fig.6, Fig.7). The density of settlement network varies considerably, but on average for the territory covered by this survey a density of 4 to 8 settlements per $100 \mathrm{~km} 2$ prevail. 


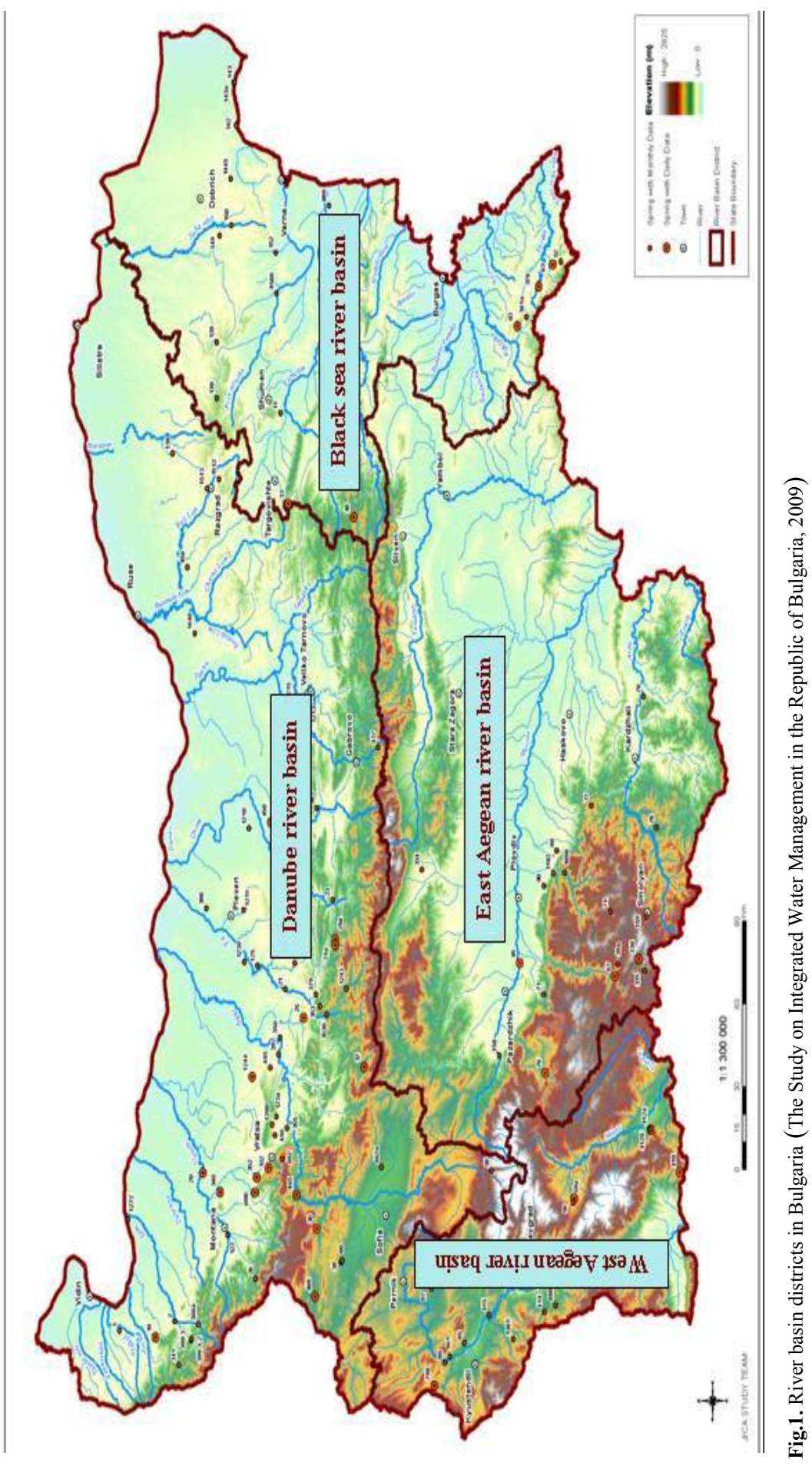




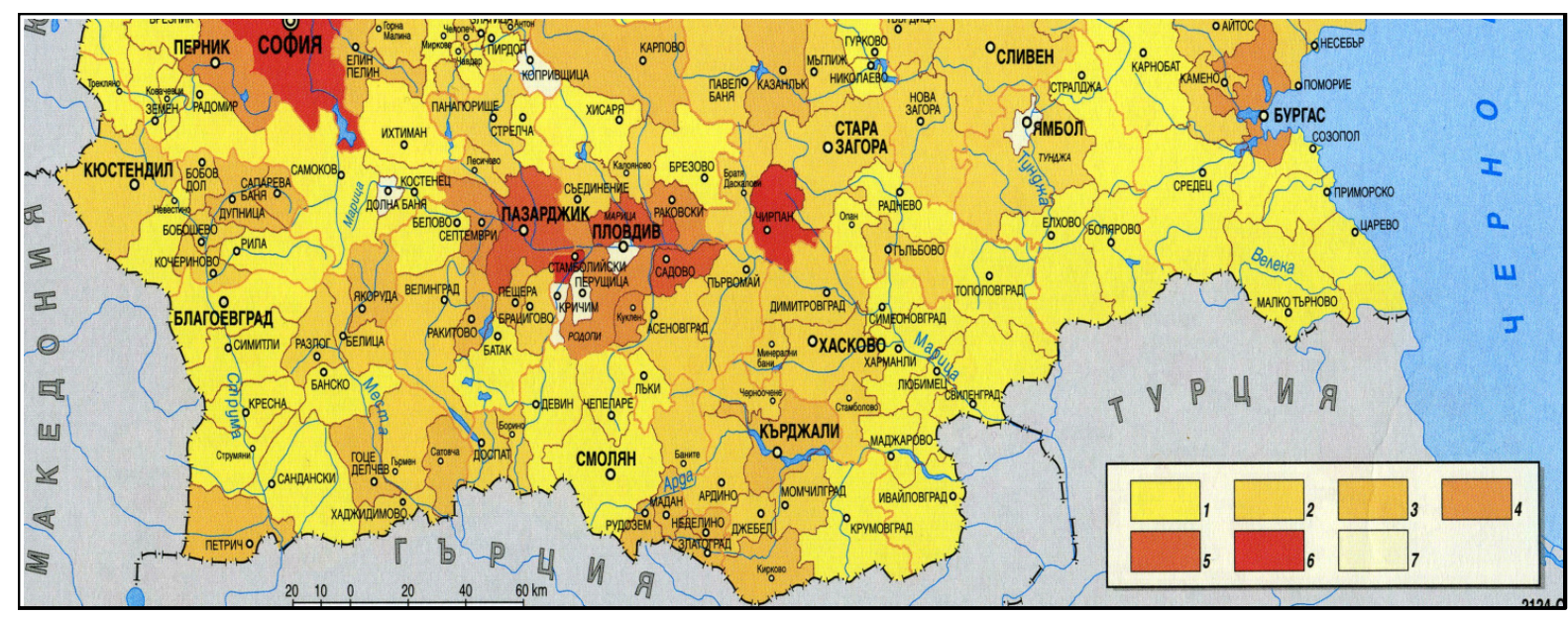

1-from 0 to 20; 2-from 21 to 40 ; 3-from 41 to 60 ; 4-from 61 to 80; 5-from 81 to 100; 6- >100; 7 - town municipalities

Fig.2. Density (persons per km2) of rural population in the municipalities from East Aegean and Weast Aegean river basin distrcts (Mladenov, 2002)

\subsection{Major economy}

A typical feature for the present development of Bulgaria in general, and of the two River Basin Regions in particular, is the ongoing process of economic system and structural transformations*. The system's transformation represents a process of reformation of the 'socialist type', planned economy into a 'capitalist type', market economy. Structural transformation involves changes in ownership structure, organizational forms, production structure, technologies, etc. Changes in the forms of ownership are related to restitution of ownership rights to agricultural lands, restitution of title to large urban real property and privatization of state owned property. At the same time, processes of de-monopolization and de-concentration of economy, restructuring of industrial sectors and of production organization forms, changes in industry structure and territorial structure of economy, its modernization and upgrading in technical and organizational terms, etc. are simultaneously under way.

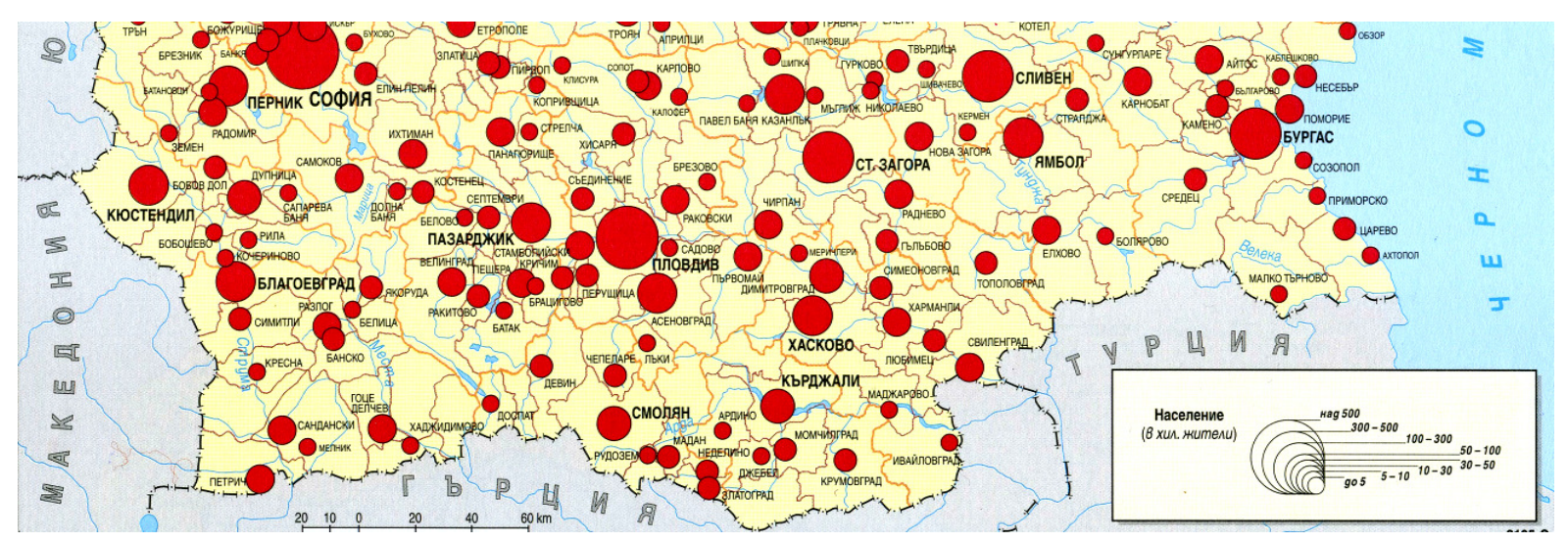

Fig.3. Distributions of the towns from East Aegean and West Aegean river basin districts according to their number of population (Mladenov, 2002

\footnotetext{
${ }^{*}$ The study refers to the year 2006 and before.
} 


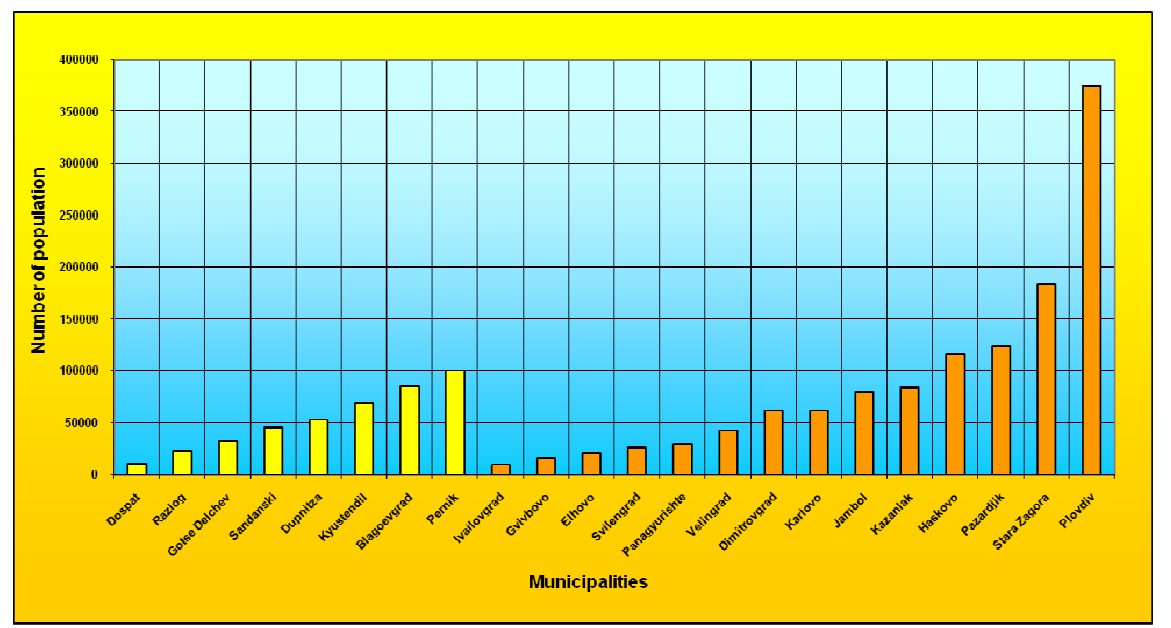

Fig.4. Number of population in West Aegean (in yellow) and East Aegean (in orange) river basin districts

The local economies of municipalities covered by this survey are characterized by an increase of tertiary sector (all types of services) and a decrease of secondary sector (industry). The primary sector (agriculture and forestry and mining industry) is currently characterized by a relative increase of its share in the gross added value, despite of the decrease in absolute value of economic activities in the sector. Regardless of the fact that the secondary sector shows a decrease in the economies covered by this study compared to the period before the transition, in most of them it still has the highest relative share $(64 \%)$. The remaining $36 \%$ are the municipalities where of priority significance is either the primary sector, or the tertiary sector, and these two groups consist of an approximately equal number of municipalities, with $18 \%$ in each group (Fig.8). With regard to municipalities where industry has the largest share, heavy industry is dominant in some $40 \%$ of them (Pernik, Plovdiv, Kazanlak, Panagyurishte, Dimitrovgrad and Galabovo), and in the remaining $60 \%$ of municipalities light industry, such as food processing, textile, tailoring businesses, is the leading sector.

In the field of agriculture a great fragmentation of land occurred in result of the process of land privatization. This unfavorable consequence strongly affects proper land use and efficiency of agricultural production. Vast areas of uncultivated lands are present all over the country, and a trend towards a decrease in agricultural production volumes is generally present. A reduction of areas and activities for production of more labor consuming and more intensive crops is registered, as well as an extension of areas allocated for non labor consuming crops.

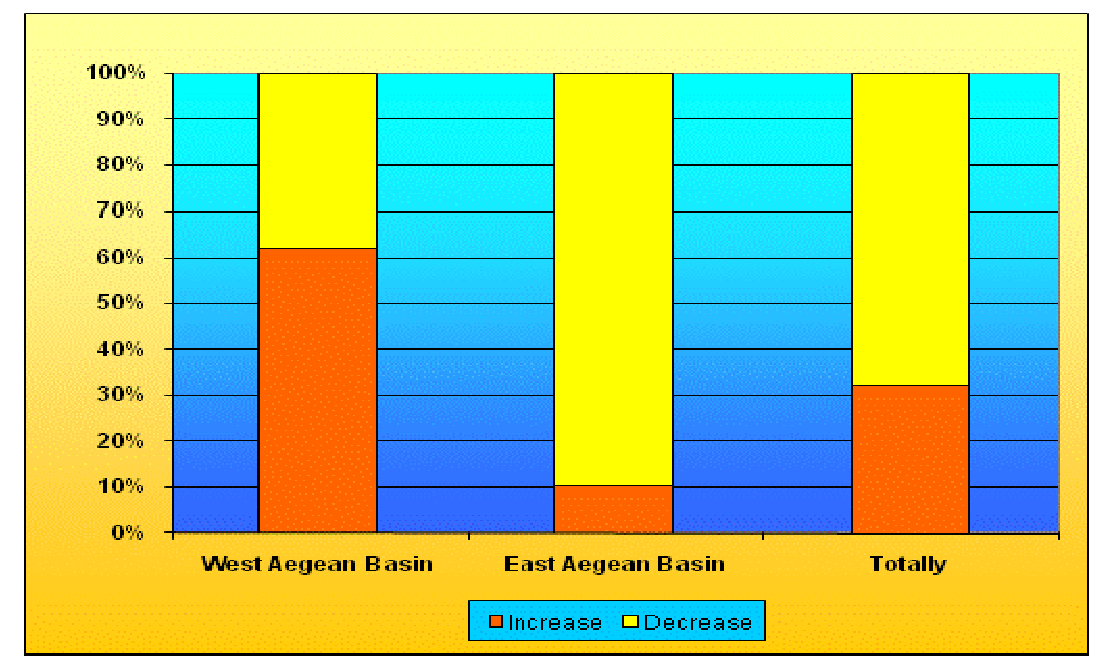

Fig.5. Distribution (\%) of the tendencies of the population number 


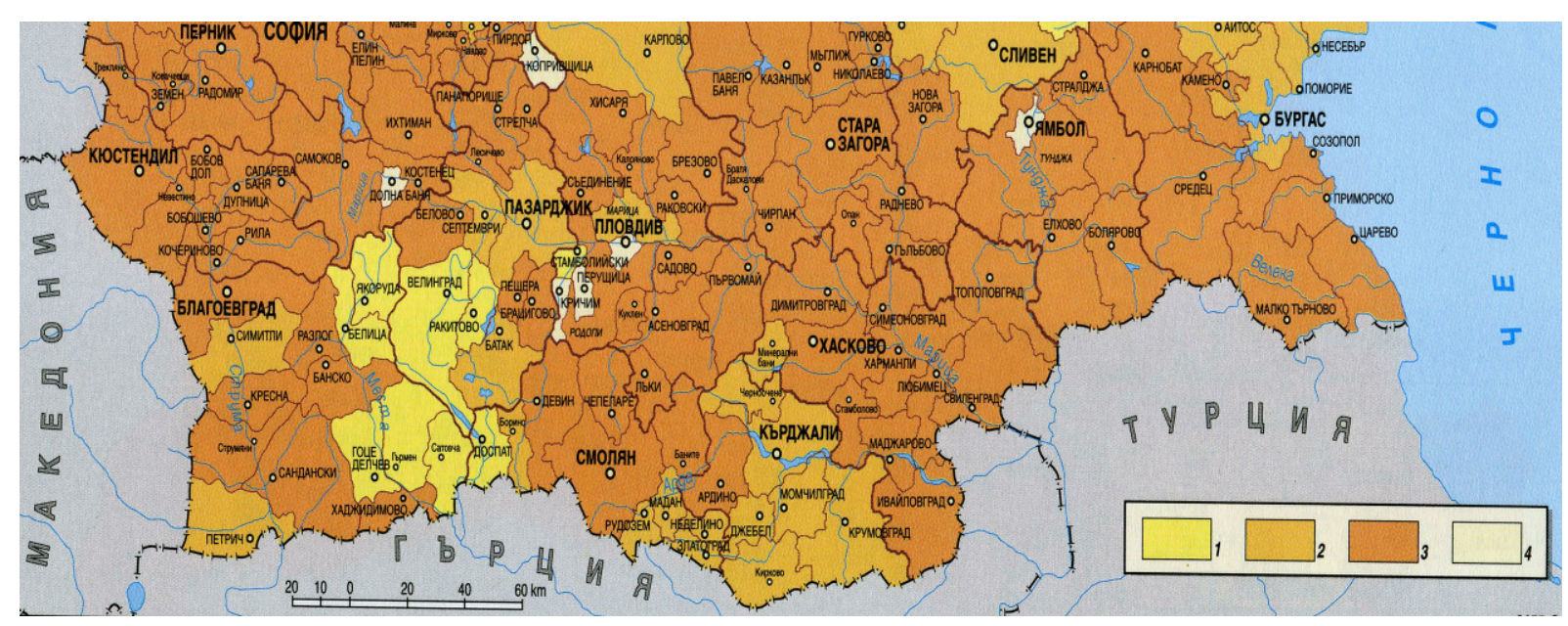

Types of age-structure: 1 - young; 2 - temperately ageing; 3 - highly ageing; 4 - town municipalities

Fig.6. Types of age-structure of rural population in East Aegean and West Aegean river basin districts (Mladenov, 2002)

There is an increasing interest towards development of hotel \& tourism businesses in many of the municipalities. In doing so, municipal communities are making efforts to identify local natural, cultural, historical and economic resources for tourism development and to improve the status of these resources.

According to the national classification scheme with regard to perspectives for targeted social and economic development (under the Law on Regional Development, 1999) the territories of the municipalities covered by this survey falls within the following categories: territories outside of targeted development regions $(55 \%)$, growth regions $(18 \%)$, regions in industrial decline $(14 \%)$, regions to be developed (9\%), and underdeveloped rural regions (4\%). At the same time, $27 \%$ of the studied municipalities fall into category of "trans-border cooperation regions" (Fig.9).

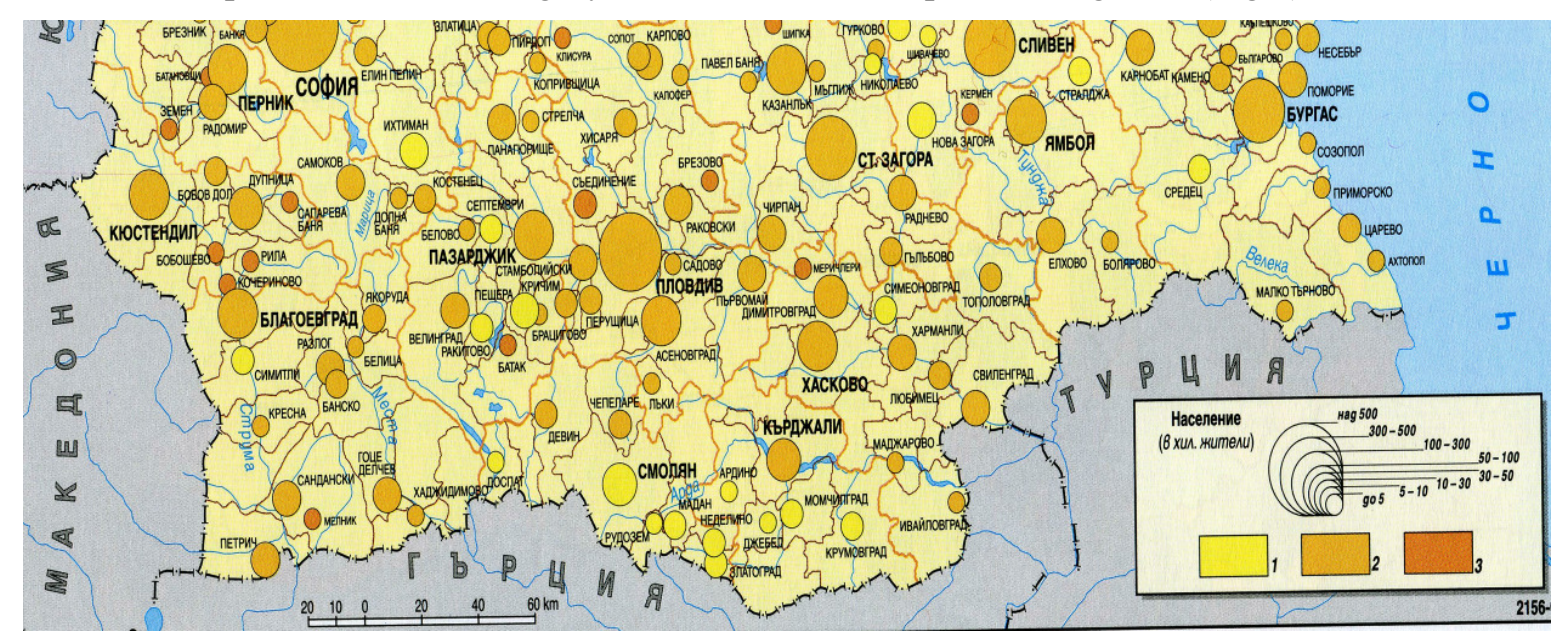

Types of age-structure: 1 - young; 2 - temperately ageing; 3 - high ageing

Fig.7. Types of age-structure of the town population in the East Aegean and Weast Aegean river basin districts (Mladenov, 2002) 


\section{Bulgaristan'ın Doğu ve Batı Akdeniz Nehir Havzalarında Su Kullanımının Yönetimi}

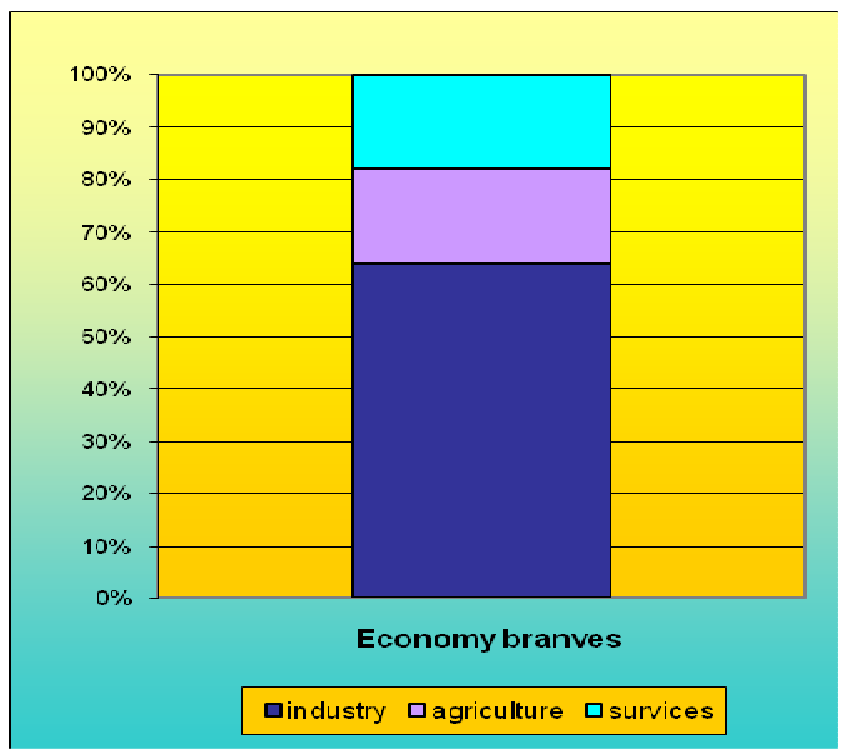

Fig.8. Distribution (\%) between main branches of economy in East Aegean and Weast Aegean river basin districts

\section{Conditions and Problems of Water Supply System}

\subsection{Water sources}

Water resources in Bulgaria in general are relatively limited - the annual average per inhabitant is $2400 \mathrm{~m} 3$ of water, compared to $7400 \mathrm{~m} 3$ in Austria and Switzerland, $6200 \mathrm{~m} 3$ in European Russia, etc. At the same time the quantity of water supplied per person per day in Bulgaria is 403 liters per person per day in average which is much more then in many other European countries; this is an evidence of unreasonable and inefficient practices of water use for drinking and household purposes.

In the municipalities covered by this study the sources of water for drinking and household purposes include both surface water sources and ground water sources (natural flow and pumped). They use open water intakes, wells, drill holes, water springs (including karst springs). Some parts of the municipalities' territory are characterized by abundant quantities of ground waters - with discharge of from 5.1 to 7.0 1/sec/km2 (Pazardzhik, Plovdiv, Velingrad, Karlovo). However, there are also locations where the discharge is below $1.0 \mathrm{l} / \mathrm{sec} / \mathrm{km} 2$ (Blagoevgrad, Ivaylovgrad, etc.) (Fig.10). 


\section{Zoya Mateeva}

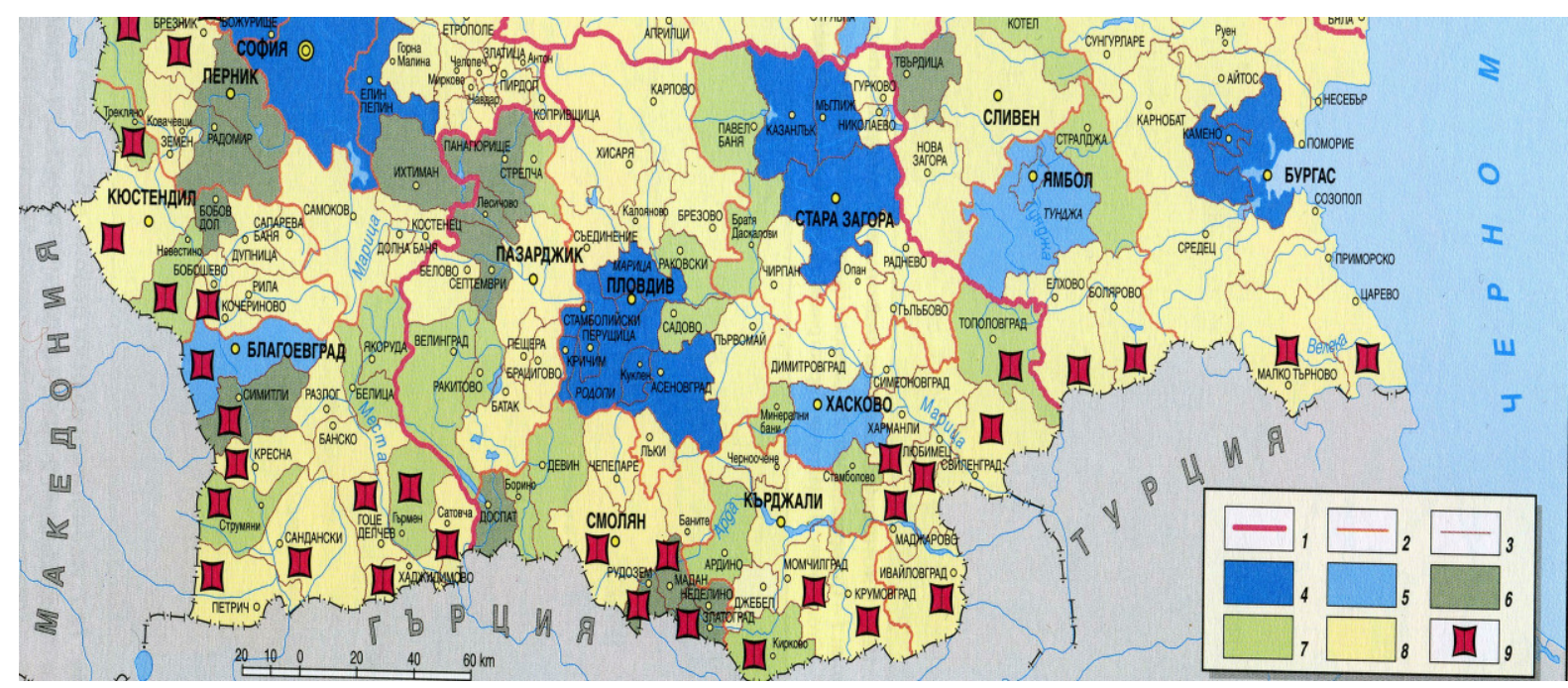

1 - boundary of region for planning

2 - boundary of province

6 - region for industrial decline

3 - boundary of municipality

4 - region for growth

5 - region for development

7 - undeveloped rural region

8 - territories out of the regions for purposeful development

9 - region for trans-boundary cooperation

Fig.9. Regions for planning and purposeful development in the East Aegean and Weast Aegean river basin districts (Kolev, 2002)

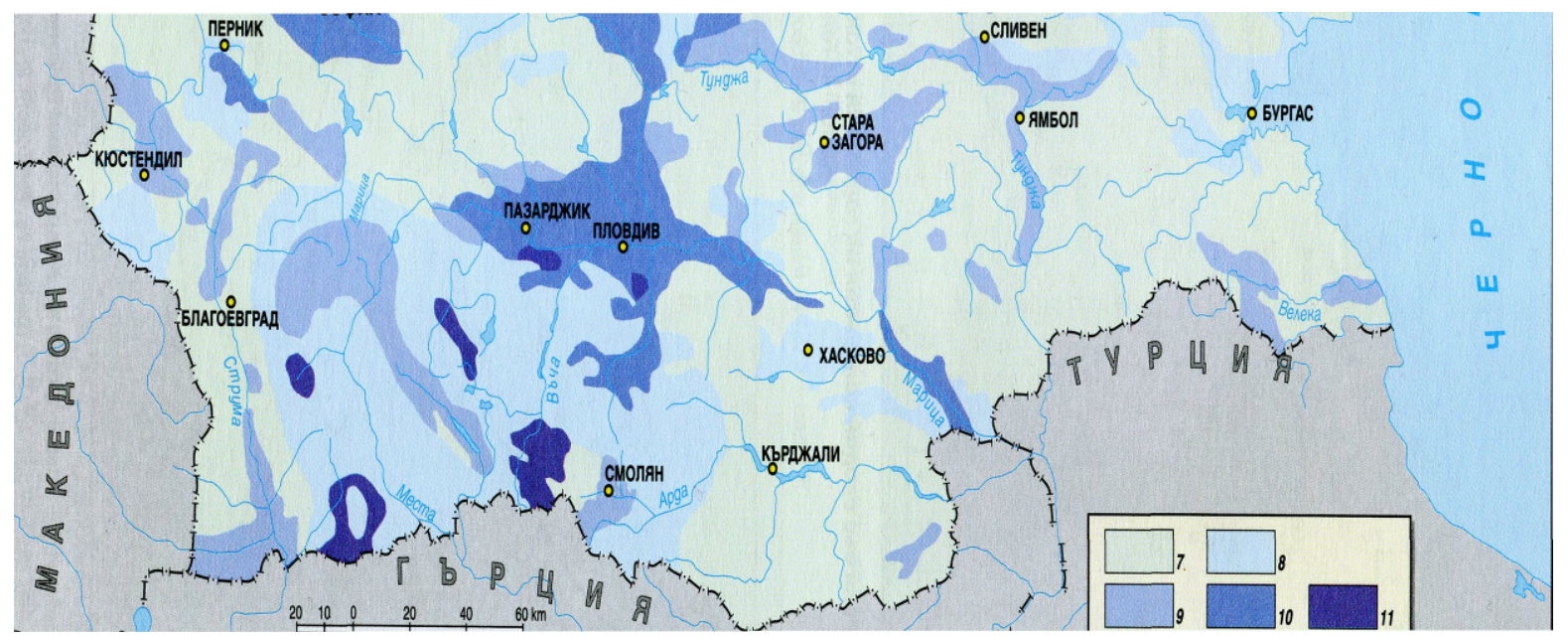

Natural flow of underground waters $(1 / \mathrm{s} / \mathrm{km} 2)$ : 7 - from 0,5 to 1,$0 ; 8$ - from 1,1 to 3,$0 ; 9$ - from 3,1 to 5,$0 ; 10$ - from 5,1 to 7,$0 ; 11$ - over 7,0 .

Fig.10. Fresh ground waters (Kehaiov, 1986)

In $64 \%$ of the municipalities the water sources are sufficient, in $18 \%$ of municipalities they on the line between sufficient and insufficient, and in $18 \%$ of the municipalities under survey the currently used water sources are insufficient. In some of the municipalities of the third group potential new water sources exist but they have not been developed so far (Fig.11). 


\section{Bulgaristan'ın Doğu ve Batı Akdeniz Nehir Havzalarında Su Kullanımının Yönetimi}

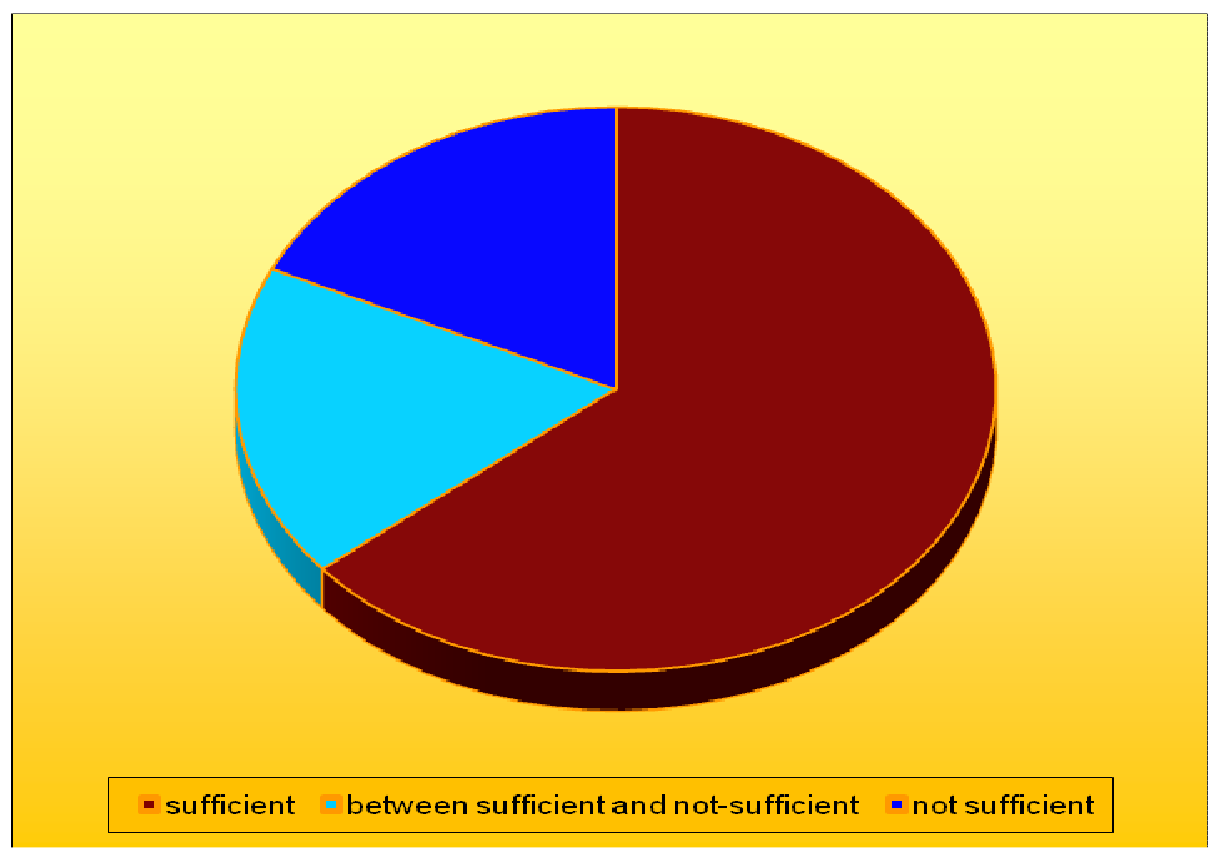

Fig.11. Distribution of water sources according to their sufficiency

\subsection{Water supply networks}

All the municipalities covered by the survey of this study have a relatively well developed water supply/sewage systems - with an average coverage of $90 \%$ for all settlements. Public water supply is available $100 \%$ in all cities and towns, and only very few of the villages lack public water supply facilities. This existing and relatively well developed system is, however, very old - at most places it has been constructed over 40 years ago, which results in high level of tear and wear and frequent malfunctions/break-downs. This causes huge water losses - often exceeding $70 \%$ which on certain occasions causes leads to temporary restrictions in water supply. One of the most dramatic problems related to public water supply in municipalities is the material the pipes were made from. In $100 \%$ of cases the greater part of the water supply networks use asbestos concrete pipes which affect negatively human health. Small portion of pipes are made of steel. In the recent years in some of the municipalities they have started works to replace old pipes with new one made of polyethylene or other high quality materials. This, however, refers only to a very small and limited area of urban municipal centers. The reasons are of financial nature - on most occasions the municipalities lack own funds to carry out such works for replacement of pipes.

\subsection{Quantity and quality of water}

The water pressure in the public water supply systems is good. The quantity of water supplied is sufficient in general. In some cases, however, temporary restrictions and/or limitations of public water supply have to be imposed, the reasons for such measures being:

- problems resulting from leakage or malfunctioning caused by aging of the system and poor state of components;

- in case of unfavorable climatic conditions - in the summertime, at high temperatures and long drought periods;

- in cases of considerable increase of water use for irrigation purposes;

- in those cases, when municipalities count on their own water sources, and when such water sources go dry. 
The problems related to water quantity have been partially solved by construction of systems of hydrologic structures, such as reservoirs, dams, pumping stations, main pipelines, pressure reservoirs and basins.

Water quality in general is good, but subject, in principle, to prior purification. In municipalities where water intake is coming predominantly from surface water sources, they receive calls from water users complaining of some turbidity (muddiness of water) following heavy rainfalls (e.g., Sandanski Municipality). In certain municipalities hosting specific industries, they inform of an increased content of chemical elements in water - for example, of manganese in Plovdiv, Dimitrovgrad, Galabovo, Yambol, Haskovo. In cases of frequent failures of water supply systems, data in evidence of deterioration of microbiological water quality exist.

\subsection{Water purification plants}

In about one half of the municipalities there are no water purification plants (WPP). In those municipalities where such facilities are available, they cover public water use only partially. Extension and renovation of existing WPP is needed, and wherever such facilities are unavailable new construction of water purification plants is required. In some 20 to $30 \%$ of the municipalities covered by this survey they have already developed projects for such construction to be carried out.

\subsection{On-going projects}

In most of the municipalities the local authorities have fully developed projects for future improvement of different phases of public water supply process. Only 14 of the projects (for all the municipalities), however, are being implemented at present. These can be sub-divided by their objectives, as follows:

- construction of new sections of the public water supply network - 5 projects;

- construction of Water Purification Plants and other modular facilities for water purification -3 projects;

- reconstruction and rehabilitation of the existing public water supply network - 4 projects;

- addition/introduction of new water sources - 1 project;

- design and construction of new reservoirs -1 project.

\section{Conditions and Problems of Waste Water Discharge and Treatment}

\subsection{Sewerage networks including the conditions of sewer pipes}

The sewage systems in the municipalities covered by this survey are built up only partially. In municipal centers and bigger towns it covers about $80 \%$ of their territory, but this percentage is much less in villages - sometimes even below $10 \%$. In villages they use septic tanks, drainage wells or septic drains. However, such structures strongly pollute soil, ground and surface waters, and disrupt ecological balance posing health hazards to public health in these villages.

In all the municipalities, except one (Municipality of Gotse Gelchev, and even there only partially) the sewage systems are of mixed type - serving simultaneously for household, industrial and rain water discharge. They are made of concrete - a material which is quite suitable for mixed type sewage systems unless additional measures have bee $\mathrm{n}$ taken at construction phase (use of sulphate resistant cement, protective tiling of inner walls or inner protective resin or foil coating).

With regard to sewage networks the major problem comes from the small diameter of pipes which in case of heavy rainfalls leads to their overflowing and subsequent flooding of buildings' basement and ground floors.

In residential areas populated with inhabitants of Roma (gipsy) descent, the flow capacity of pipes is reduced to $80-90 \%$ due to disposal of all types of solid waste into the sewage system. 
On many occasions main and secondary sewage lines and branches pass under residential buildings, industrial premises or cross private lands which makes impossible or difficult maintenance and proper operation of the sewage system.

Large sections of the now existing sewage network are in a very poor technical condition due to their wear and tear, or have been destroyed.

\subsection{Living, industrial and livestock waste water treatment}

In $77 \%$ of the municipalities covered by our survey, there are no plants or complex facilities for treatment of mixed waste waters originating from households, industry and agriculture (Fig.12). Waters are discharged into water collectors or discharged directly into the rivers. The collectors (waste water collection structures) are made basically of concrete pipes with poor quality of joints and insufficient compaction of reverse slope which causes numerous cases of subsidence and leakage.

Some of industrial companies use local waste water treatment plants before points of discharge of waste waters into the rivers. In some cases waste waters are treated only partially by mechanical treatment, by sedimentation and removal of sediments. There are cases of specific (specialized) treatment of waste waters; details on such cases of specific treatment are included in Application 3. The sediments can not be used as fertilizers (they've been classified as dangerous) and are being stored temporarily at the WWTP site.

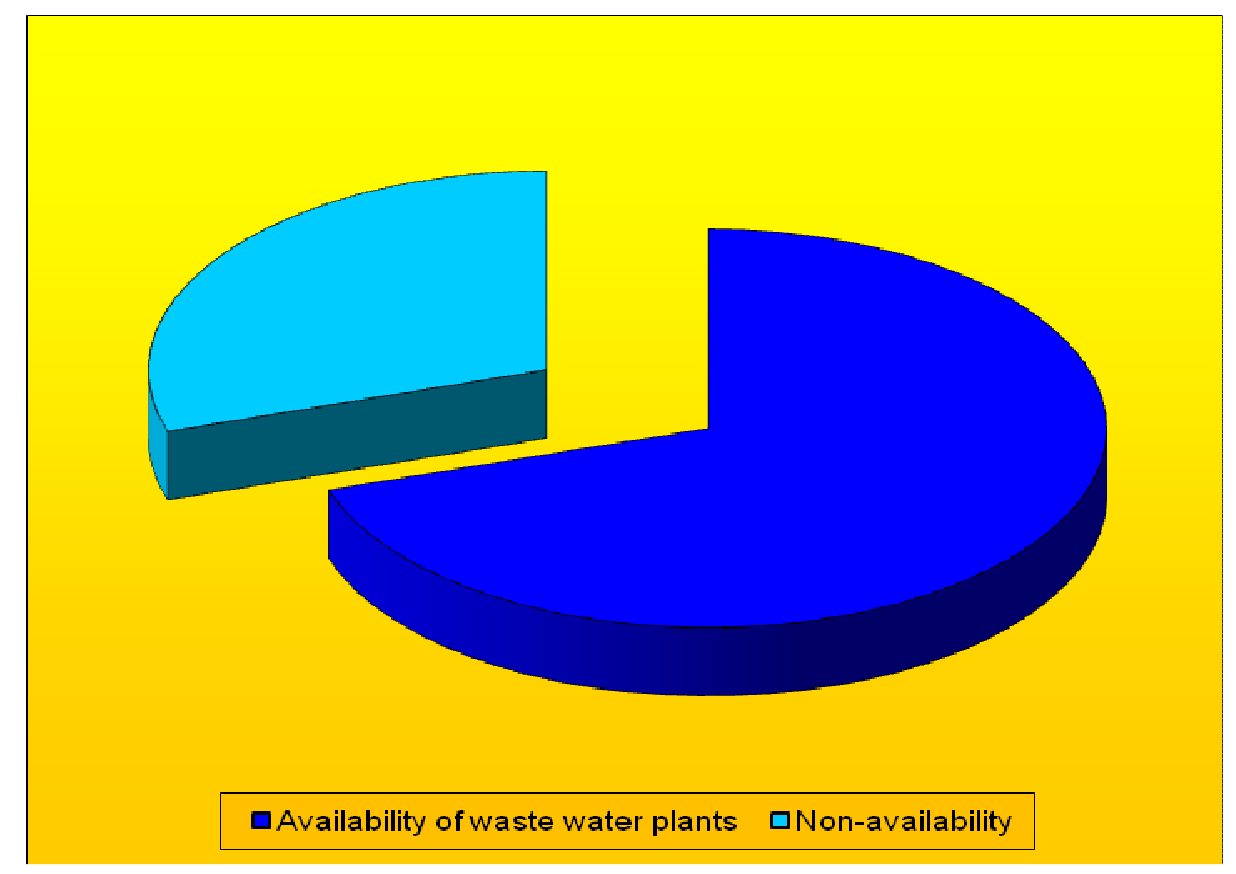

Fig.12. Distribution (\%) between availability/non-availability of waste water plants in East Aegean and West Aegean river basin districts

The most significant problems related to local waste water treatment plants and facilities are:

- collection and treatment of extracted fats and waste oil products;

- need of establishing a centralized system for collection, removal/transportation and treatment/recycling of extracted waste substances and pollutants from local waste water plants and facilities. 
Very often the substances extracted in the process of water treatment at WWTP and facilities are been discharged back into the sewage system, thus creating more problems with regard to waste water treatment.

\subsection{Ongoing projects and plans}

In most of municipalities there currently are already developed projects aiming at improvement of various phases of water intake and water supply processes. Some of such projects have actually been started and are now being implemented. The ongoing projects can be sub-divided into the following groups:

- reconstruction of sewage networks - 6 projects;

- construction of new sewage networks - 18 projects;

- construction of waste water collectors, modular structures and facilities and WWTP (Waste Water Treatment Plants) - 10 projects.

\section{Other problems related to water}

\subsection{Accidental pollution}

The traditional concepts of the modern water economy policy for together use of the water objects as water sources and water intakes of waste and polluting substances, as well as for the exceptional role of their purification, are well known. These formulations, however, are practically refuted because regardless of the built purification capacities, the waste substances exhaust irreversibly the quality of the potential water resources. The purification capacities are ecologically ineffective because the established technologies do not entirely recover the natural qualities of the water objects. The polluting substances, especially in the big urbanized and industrial centers, are multicomponent and are not liable to absolute neutralization, regardless of the perfection of purification technologies.

In $44 \%$ of the studied municipalities there is evidence for accidental pollution, which occurred in a volley-like manner, regardless of the constant background of pollution. Only in one of these cases the pollution origin is connected with abundant precipitation. In the other cases the pollution is treated as anthropogenic, mostly related to the activity of the industrial enterprises.

Concerning the consequences for the biota, the most frequent information refers to damages on fish. There are no data about any effects on human health.

The measures that have been undertaken are of the following types:

- stopping the water supply

- sending signals to RIEW

- imposing single sanctions

\subsection{Floods}

The floods are typical phenomena for the regime of the rivers in Bulgaria, which increase the water resources on the one hand but provoke destructive floods and accelerate the erosion-denudation and accumulative processes.

With respect to the extent of the torrential character of the rivers, a sharp difference is observed for the two basin regions - the West Aegean one is characterized by low torrential rivers (with the exception of the Kyustendil region) and the East Aegean one is characterized by medium to strongly torrential rivers (Fig. 13). 
Eighty seven percent of the municipalities that submitted information about the topic report cases for flooding that occurred in the last years. The adjacent territories of the rivers in the lands of the studied municipalities were affected during the floods. The population suffered mainly material damages - flooded homes, roads, administrative and industrial building, agricultural lands, sewerage systems and infrastructure.

Emergency-recovery activities were carried out as drainage, disinfection of flooded areas, stabilization of earth dikes, cleaning of riverbeds and emergency discharge of dams. The cleaning of riverbeds and the adjacent lands continues in order to prevent new floods.

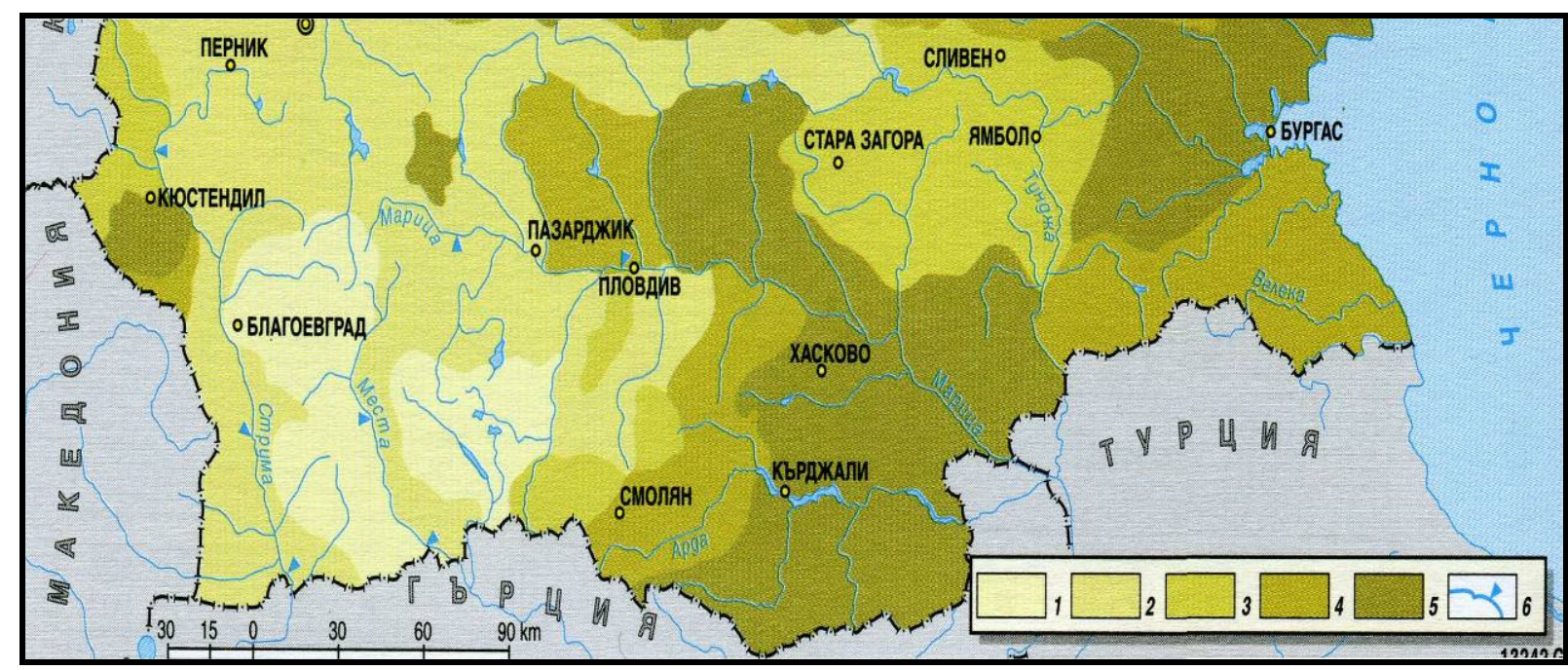

1 - most weakly torrential rivers

2 - weakly torrential rivers

3 - temperate torrential rivers
4 - highly torrential rivers

5 - most highly torrential rivers

6 - river part with hydrological station

Fig.13. Flood degree of the rivers from East Aegean and West Aegean river basin districts (Zyapkov, 2002)

\section{Conclusions and recommendations}

The results of the study revealed a large gap between the current water status in the country and the "good water status" defined by the EU-WFD. In order to achieve the "good water status" and to realize a sustainable use of water resources, programs of various measures should be implemented.

New WWTPs should be constructed and the existing WWTPs and sewer networks should be rehabilitated in order to improve the present water quality in the levels of Class III to V to the levels around the middle of Class II and III in EABD and WABD. Water quantity in the EABD and WABD should be improved by the improvement of domestic water supply systems and by the improvement of irrigation facilities. The managing tools of GIS Data Model and Integrated Water Management Models should be maintained and updated for sustainable and effective river basin management.

The following basic studies should be conducted too:

- The study on flood and sediment control for the purposes of prevention from flood damages and controlling sand and gravel extraction, etc.

- The study on pressures and impacts from discharges of priority harmful substances and heavy metals, to protect people from possible hazard, caused by toxic substances. 


\section{Zoya Mateeva}

\section{References}

Hydrologic reference book of rivers in Bulgaria. 1982. vol.2,3, Sofia, Bulgaria.

Kehaiov, T. 1986. Ground waters. Encyclopaedia of Bulgaria, vol.5, BAS Ppubl.house, Sofia, Bulgaria.

Kolev, B. 2002. Historical review of the socio-economic regioning. Editors: Kopralev, Il. et.al., Geography of Bulgaria, ForCom Publ.house, Sofia, Bulgaria.

Kopralev, Il. (ed.). 2002. Geography of Bulgaria. Sofia, Bulgaria.

Mladenov, Ch. 2002. Population density and distribution. Editors: Kopralev, Il. et.al., Geography of Bulgaria, ForCom Publ.house, Sofia, Bulgaria.

The Study on Integrated Water Management in the Republic of Bulgaria. 2009. Draft Final Report. JICA CTI Engineering International Co., Ltd. Manuscript.

Varbanov, M. 2002. Hydrographic characteristic. Kopralev, Il. et.al., Geography of Bulgaria, ForCom Publ.house, Sofia, Bulgaria.

Yordanova, M. 1978. Internal year distribution of river flow in East Rhodopes - result from the complex influence of the physical-geographical factors. Ph.D. thesis, Institute of geography, BAS, Sofia, Bulgaria.

Yordanova, M. and Z. Mateeva. 2011. The nature potential of mountains in Bulgaria and its sustainable use. Editor(s): Zhelezov,G., Sustainable Development in Mountain Regions: Southeastern Europe, Springer, London-New York.

Zyapkov, L. 2002. River floods. Editors: Kopralev, Il. et.al., Geography of Bulgaria, ForCom Publ.house, Sofia, Bulgaria. 